doi:10.18575/msrs.sm.e.16.17 UDK 616.711-007.43 COBISS.RS-ID 6163480

\section{The Significance of Foraminotomy in Lumbar Herniated Disc Surgery}

\section{ABSTRACT}

Introduction: Spinal column represents a strong and flexible body axis. It is consisted of vertebrae which are connected by the intervertebral disk and solid fibrous joints.

Aim of the Study: To ascertain whether or not and to what extent foraminotomy affects the final outcome of lumbar herniated disc surgery.

Patients and Methods: This retrospective study analyzed 71 patients who were operated at the Clinic of Neurosurgery in Banja Luka, in the period from 2009 to 2016. Extirpation of disc was performed in 41 respondents, while in 30 patients, a nerve root was further alleviated, along with the extirpation of disc. All patients were operated under the same conditions.

Results: There was no statistically significant difference in the age of women and men who underwent classical discectomy and foraminotomy. There was a statistically significant difference in the disc protrusion and extrusion in patients who underwent conventional discectomy and those who underwent foraminotomy, along with conventional discectomy. There was no statistically significant difference in diagnosis in respondents who underwent conventional discectomy and those who underwent foraminotomy, along with conventional discectomy. There was statistically significant difference in the severity of pain in patients who underwent conventional discectomy and those who underwent foraminotomy, along with conventional discectomy. There was a statistically significant difference in clinical recovery, where the findings were in favor of the respondents who underwent foraminotomy, compared to the respondents who did not.

Discussion: The treatment of this syndrome is complex, multidisciplinary and with problematic success, and in cases when the operation is performed, the results are not as good as in the primary operation.

Conclusion: The results of this study show that the patients who underwent foraminotomy during the operation of prolapsed lumbar disc have a clinically better result.

Keywords: foraminotomy, discectomy, protrusion, extrusion

(Scr Med 2016:47:100-105)

\section{Ostoja Savić, Dušan Janičićc Božo Krivokuća ${ }^{3}$}

${ }^{1}$ Clinic of Neurosurgery, University Clinical Centre of the Republic of Srpska, Banja Luka 2 Department of Thoracic Surgery, University Clinical Center of the Republic of Srpska, Banja Luka ${ }^{3}$ Clinic for General and Abdominal surgery, University Clinical Center of the Republic of Srpska, Banja Luka

\section{Contact address:}

Ostoja Savić

Zdravka Korde 1 78 ooo Banja Luka, Republic of Srpska Bosnia and Herzegovina Telephone: +38765877545 e-mail:duskasavic@hotmail.com

Submitted: June $16^{\text {th }}, 2016$ Accepted: July 11 ${ }^{\text {th }}, 2016$ 


\section{Introduction}

Spinal column represents a strong and flexible body axis. It is consisted of vertebrae which are connected by the intervertebral disk and solid fibrous joints.

The spine is constantly under the force of gravity pressure and the transfer of body weight which is increasing from top to bottom. Hence, vertebrae are more massive. ${ }^{1}$ Dynamic segment is consisted of two vertebrae connected with the following: discus, ligaments, facet joints, paravertebral muscles and fascia.

The disc functions as a joint and absorber that is able to withstand a load of $500-600 \mathrm{~kg}$. It is a fibrous-cartilage plate with a protruding upper and lower surface which is firmly attached to the vertebral end plate. Two parts are distinguished at a disc, that is, external and internal. The external one, annulus fibrosus, strongly abuts vertebrae and is built around diagonally placed fibers. ${ }^{2}$ The internal one, nucleus pulposus, doesn't have its own vascularization. ${ }^{2-4}$ Discs are additionally connected with ligaments anterior longitudinal et posterior that prevent excessive bending backward and forward. By discus lowering, ligg.flava leads to hypertrophy of the discus whose "harvesting" additionally narrows the canal at the posterior side. ${ }^{5}$ Disc herniation, in a form of protrusion, extrusion and subligamentous extrusion leads to pain in the back and / or leg, sensory and motor disorders, and in the most unfavorable variant, it causes sphincter and erectile dysfunction. The problems are clinically manifested via positive Lazarevic's sign.

Diameters of the spinal canal that are, so to speak, considered physiological are as follows: the central is 14 $\mathrm{mm}$ and more, bipedicular distance is $18 \mathrm{~mm}$, the width of the lateral recess is $4 \mathrm{~mm} .^{6,7}$

Lumbar radiculography had been the method of choice in the diagnosis of discopathy until the 80's when it lost its primacy over magnetic resonance imaging (MRI) and computed tomography (CT) which provided a threedimensional image of discuse. ${ }^{7}$

In $90 \%$ of patients with the disc prolapse, the treatment is conservative, whereas other lo\% require surgical treatment ${ }^{7-10}$ Surgical treatment is indicated in cases when the effects of conservative treatment are absent and radicular pain episodes become more frequent and accompanied with the development of sudden neurological deficit such as urinary incontinence or progressive motor weakness. ${ }^{8,9}$

The fact that in 5-40\% of treated patients, pain or leg pain continued after the surgery (FBSS) (Failed Back Surgery Syndrome) emphasises the importance of rigorous selection of the patients requiring surgery. ${ }^{7-10}$
The most common surgical causes of FBSS (Failed Back Surgery Syndrome):

\section{- Recurrent herniation}

- $\quad$ Fragment of disc still pinching a nerve

- Lateral stenosis

- $\quad$ Facet joint trauma with or without synovial cysts

- Central stenosis

In the US, $12 \%$ of excused absence is due to this problem with the financial implications that are measured in billions of dollars. ${ }^{10}$

\section{Aim of the Study}

To ascertain whether or not and to what extent foraminotomy affects the final outcome of lumbar herniated disc surgery.

\section{Patients and Methods}

This retrospective study analyzed 71 patients who were operated at the Clinic of Neurosurgery in Banja Luka, in the period from 2009 to 2016. Extirpation of disc was performed in 41 respondents, while in 30 patients, a nerve root was further alleviated, along with the extirpation of disc. All patients were operated under the same conditions and all indications were set based on the anamnesis, clinical imaging and diagnostic procedures: MRI, CT scan, lumbar radiculography or a combination of some of these methods. Postoperative treatment was the same: a stationary balneotherapy began four weeks after the surgery and lasted four weeks. Parameters that were monitored in the respondents were as follows: the length and intensity of pain before the surgery, the pain after surgery, neurological deficit before and after surgery, as well as the time that was required to return to work. The patients were analyzed by sex, age and profession.

\section{Results}

This retrospective study was consisted of 71 patients and divided into two groups .The first group was consisted of $41(57.7 \%)$ respondents who underwent conventional discectomy, while the other group was consisted of 30 (42.3\%) respondents who underwent foraminotomy, along with conventional discectomy. There were 37 (52.1\%) women and 34 (47.9\%) men. Average age of all the respondents was 44.34 years, that is, in the group that underwent foraminotomy, it was 44.67 , while in the group that did not undergo foraminotomy, it was 44.10. There was no statistically significant difference in the age of women and men treated with the use of conventional 
discectomy and foraminotomy $(\mathrm{p}=0.1194)$.

Dyscopathies were the most frequent in the respondents whose job implied poor body posture, long sitting and standing (43.7\%). Furthermore, dyscopathies were present in the respondents who were conducting vigorous physical labor (23.9\%), intellectual professions (22.5\%) and moderately vigorous physical labor (9.9\% ).

In $40.8 \%$ of patients problems lasted less than 3 months, in 21 . 1\% they lasted 3 to 6 months, and in $38 \%$ the problems lasted more than 6 months. High intensity pain before the surgical treatment was present in $33.8 \%$ of respondents, the pain of medium intensity in $42.3 \%$ and the pain of light intensity in $23.9 \%$ of respondents. The pain of high intensity was present in 13 patients who underwent foraminotomy and in 20 patients with the same intensity of pain who did not undergo foraminotomy.

Neurological deficit was present in $53.5 \%$ of respondents. The severe deficit which was manifested through minimum contractions that were felt only under the fingers was present in $1.4 \%$ of respondents. $9.9 \%$ of respondents moved in the direction of gravity, $28.2 \%$ moved against the gravity but did not overcome the resistance, while $7 \%$ of respondents moved against gravity and overcame the resistance. Before the surgery, three patients had sphincter dysfunctions that were clinically manifested in urinary disorders and defecation. In two subjects, foraminotomy was not performed, while in one it was.

Before the operation, 50 (70.4\%) respondents were able to walk 100 meters, $6(8.5 \%)$ respondents between loo and 300 meters, while 15 (2l.1\%) respondents were able to walk over 300 meters.

Disc protrusion was present in 34 (47.9\%) respondents and disc extrusion in 30 (42.3\%), sequestering in $1.4 \%$, migration in $5.6 \%$, and degenerative changes in $2.8 \%$ of respondents. In the group where foraminotomy was performed, the protrusion was verified in $52.9 \%$, extrusion in $30 \%$ and migration in $25 \%$ of respondents. In the group where foraminotomy was not performed, the extrusion was present in $70 \%$, protrusion in $24 \%$ and migration in $6 \%$ of respondents. There was a statistically significant difference in the disc protrusion and extrusion in patients who underwent conventional discectomy and those who underwent foraminotomy, along with conventional discectomy $(\mathrm{p}=0.0116)$.

MRI was used for diagnosing in 28 respondents (39.4\%), CT in 12 (16.9\%) and lumbar myelography in 8 (11.3\%) respondents. The combination of CT and myelography was used in $13(18.3 \%)$ respondents. All diagnostic procedures were conducted in $3(4.2 \%)$ respondents.

The most commonly affected intervertebral area was the L-V. (Figure 1.) There was no statistically significant difference in diagnosis in patients who underwent conventional discectomy and those who underwent foraminotomy, along with conventional discectomy ( $\mathrm{p}=$ 0.0771)

\section{Figure 1. The affected intervertebral area according to groups}

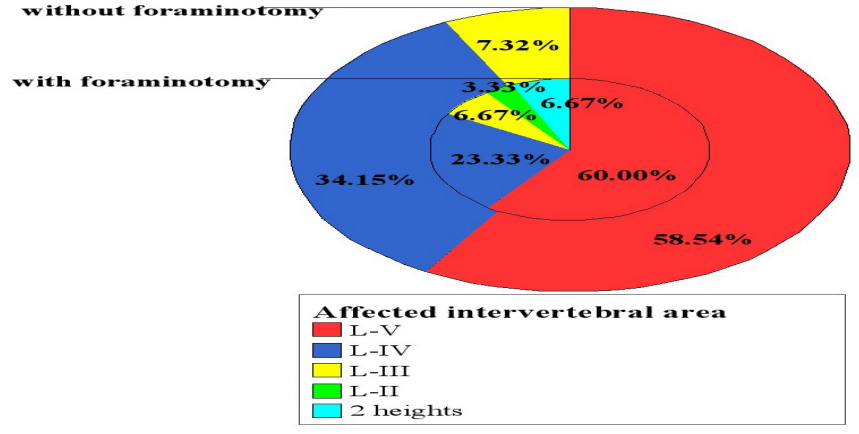

The most common operational approach, conducted on $73.2 \%$ of respondents, was interlaminectomy. Hemilaminectomy was performed in $23.9 \%$ of respondents and flavectomy in $2.8 \%$. Intraoperative findings confirmed the protrusion of intervertebral discs in $46.5 \%$ of respondents, extrusion in $43.7 \%$, sequestration in $2.24 \%$ and migration in $7,32 \%$ of respondents. (Figure 2.)

Figure 2. Intraoperative findings according to groups

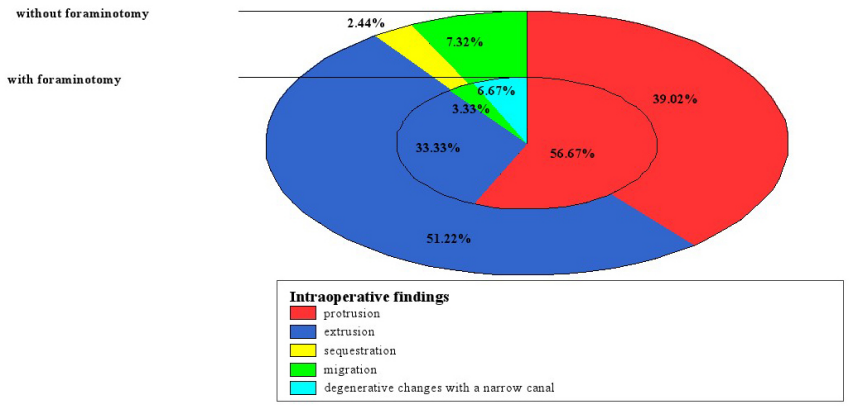

After the operation, $26.8 \%$ of respondents did not feel pain, intermittent pain of medium intensity was present in $43.7 \%$, and the pain of medium intensity was present in $29.6 \%$ of respondents. Postoperatively, $3 / 4$ of patients had normal movements of full-scale and none of the patients suffered from sphincter dysfunctions. There was a statistically significant difference in the severity of pain in patients who underwent conventional discectomy and those who underwent foraminotomy, along with conventional discectomy $(\mathrm{p}=0.0116)$.

$95.8 \%$ of respondents were able to walk over 300 meters after the surgery. Furthermore, after the surgery, $64.8 \%$ of respondents returned to their full-time employment, $4 \%$ of 
respondents returned to the part-time employment, $21.1 \%$ changed their job, while $12.7 \%$ of respondents retired. More patients (71.8\%) who had undergone foraminotomy returned to their previous workplace.

Figure 3. Neurological weakness after the surgery according to groups

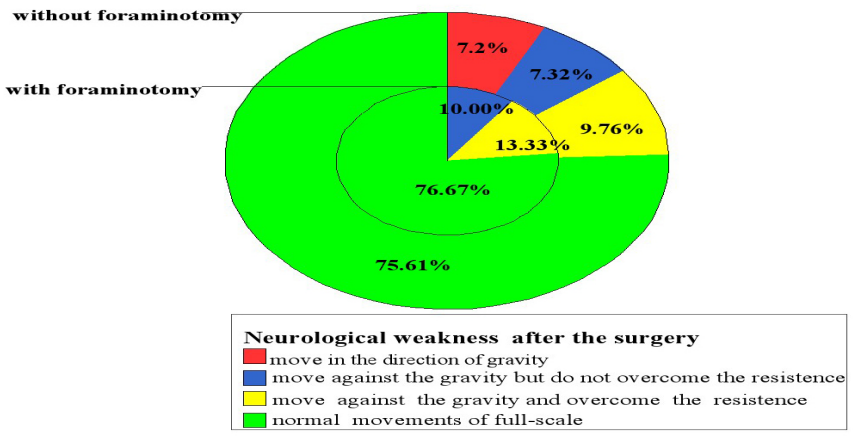

After the surgery, none of the respondents had pain of high intensity. Postoperatively, neurological findings in patients who did not undergo foraminotomy were as follows: 22 patients had regular neurological findings before and after the surgery, 12 patients exhibited neurological improvement, while in 7 patients, pre-existing neurological deficit remained after the surgery. (Figure 3.)

In terms of neurological deficit, in the group of patients who underwent foraminotomy, the results were as follows: 16 respondents had normal neurological findings preoperatively and postoperatively, the improvement of neurological deficit occurred in 11 patients postoperatively, while in 3 patients, pre-existing neurological deficit remained after the surgery.

The analysis of walking functions before and after the surgery in the group of patients who did not undergo foraminotomy showed the following: 31 patient improved, while 10 patients remained at the preoperative level. The respondents presented satisfying length of walk after the surgery.

There was a significant statistical difference in clinical recovery - finding in favor of the patients who underwent foraminotomy compared to those who underwent only conventional discectomy $(p=0.0249)$. In the group who underwent foraminotomy, 22 patients showed the improvement in terms of the length of walk, while 8 respondents remained at preoperative level. The respondents presented satisfying length of walk.

\section{Discussion}

Verbiest i sar. In their study, Verbiest et al. examined 86 patients operated due to lumbar herniated disc. The disc extirpation was performed in 41 respondents, whereas in the remaining 45 respondents, the additional release of roots in the intervertebral foramen -foraminotomy was done. Out of the total number of treated patients, $84.8 \%$ of respondents who had undergone foraminotomy and $64.3 \%$ who had not, completely returned to their profession.?

In the examined series, MRI was used preoperatively in $40 \%$ of patients and it was a sufficient tool for diagnosis. The most common combination used in diagnosis was: CT and myelography in $18 \%$ of cases. In $30 \%$ of cases it was necessary to conduct two or more diagnostic procedures.

In his study, Davis stated that intraoperatively, in $90 \%$ of respondents it was the case of disc extrusion or protrusion which correlated with intraoperative one in $85 \% .8$ In the examined series, sphincter dysfunctions occurred in 3 patients who had not had them postoperatively.

In his study, Lewis stated that, before the surgical treatment, $52 \%$ of patients had normal neurological findings, while $48 \%$ had a motor deficit which was more or less pronounced. ${ }^{9}$

In his series, S. Shapiro examined 64 patients who had motor deficit preoperatively and the following results were obtained: motor deficit remained in 8 respondents, it improved in 22 respondents, while the complete neurological recovery occurred in 34 respondents. ${ }^{10}$ If there is a neurological deficit in the clinical picture, (qaudae equinae syndrome) a relatively good result can be expected in terms of recovery of function of the sphincter, but solely in cases when the operation is done in the first 48 hours. ${ }^{10}$

In the examined study, six months or more was necessary for $54.9 \%$ of operated respondents to return to work.

DeOrio JK states that the intervertebral area is affected by herniated disks, LV and LIV in 90\% of cases. In $60 \%$ of cases it is LV herniation and in about $30 \%$, it is LIV." In the examined series, the localization of herniation of intervertebral discs was identical.

In the study conducted by Law JD, out of total number of respondents who had undergone foraminotomy, 54.9\% returned to work within 3 months. ${ }^{12}$ Operation of lumbar disc in adolescents and children shows similar results as with adults, with more frequent occurrence of trauma. ${ }^{12}$

During the follow-up of these patients in the postoperative period, the need for reoperation occurred in about $80 \%$ of cases.12 Perennial monitoring of patients with herniated lumbar disc, without neurological deficit and who were treated conservatively, showed a solid recovery in $90 \%$ of cases. $^{12}$

By group analysis in the examined series, we can notice that, in the group of respondents, more of them returned to 
their profession completely, while in the control group, the percentage of those with an easier job was slightly higher than in the group of respondents, while the percentage of retired respondents was similar in both groups.

Foraminotomy is frequently performed within reoperation, suggesting that the performance of the same during the disk operation would have its justification. ${ }^{8}$

\section{Conclusion}

The results of this study show that the patients who underwent foraminotomy during the operation of prolapsed lumbar disc have a clinically better result. Proper selection of patients for surgery is crucial in order to accomplish good results: clinical picture, correct diagnosis, absence of a favorable response to conservative treatment within 4 months. The treatment of this syndrome is complex, multidisciplinary and with problematic success, and in cases when the operation is performed, the results are not as good as in the primary operation.

\section{Reference}

1. Garg M,Kumar S. Interlaminar discectomy and selective foraminotomy in lumbar disc herniation/ J. Orthop Surg/ Hong Kong 2001 Dec.9 (2): 15-18. http://dx.doi.org/10.1177/230949900100900204

2. Thongtrangan I. Le H. Parh J. Kim DH - Minimaly invasive spinal surgery - historical perspective. Neurosurg Focus. 2004. Jan.15.16(1): E 13.

3. Ahn Y. Lee SH, Park WM, Lee HY - Posterolateral percutaneous endoscopic lumbar foraminotomy for $\mathrm{L}-\mathrm{V} /$ S-I foraminal or lateral exit zone stenosis technical note $\mathrm{J}$ Neurosurg 2003. Oct.99 (3 suppl): 320-3.

4. Singh Kern, Eric Ledet, Allen Carl. Intradiscal therapy, Spine
2005. vol.30

5. Abramowitz JN, Neff SR. Lumbar disc surgery:results of the prospective lumbar discectomy study of the Joint Section on Disorders of the Spine and Peripheral nerves of the American Association of Neurological Surgeons and the Congress of Neurological Surgeons. Neurosurgery 1991; 29(2): 301-308. http://dx.doi.org/10.1227/oooo6123-199108000-00027

6. Modic MT, Ross JS. Magnetic resonance imaging in the evaluation of low back pain. Orthop Clin North Am 1991; 22:283-301. PMid:1826552

7. Verbiest H.Lumbar spinal stenosis morphology, classification, and long- term results.In Weinstein J, Wiesel S, eds The lumbar spine.Philadelphia: WB Saunders, 1990:546-585

8. Davis RA: A long-term outcome analysis of 984 surgically treated herniated lumbar disc. J Neurosurg 80:415-421, 1994.

http://dx.doi.org/10.3171/jns.1994.80.3.0415

PMid:8113853

9. Lewis PJ, Weir BK, Broad RW, Grace MG: Long-term prospective study of lumbosacral discectomy. J Neurosurg 67:49-53, 1987.

http://dx.doi.org/10.3171/jns.1987.67.1.0049 PMid:3598671

10. Shapiro S: Medical realities of cauda equina syndrome secondary to lumbar disc herniation. Spine 25:348-352, 2000.

http://dx.doi.org/10.1097/00007632-200002010-00015 PMid:10703108

11. DeOrio JK, Bianco AJ: Lumbar disc excision in children and adolescens. J Bone Joint Surg Am 64: 991-996, 1982. PMid:6214560

12. Law JD, Ralph RAW, Kirsch WM: Reoperations after lumbar intervertebral disc surgery. J Neurosurg 48: 259, 1 


\section{Značaj foraminotomije kod operacije lumbalne discus hernije}

\section{SAŽETAK}

Uvod: Kičmeni stub predstavlja snažnu i elastičnu osovinu tijela. Sastoji se od pršljenova koji su međusobno povezani intervertebralnim pločama i čvrstim fibroznim vezama.

Cilj rada: Doći do saznanja da li i u kojoj mjeri foraminotomija utiče na konačni ishod operacije hernije lumbalnog diska.

Ispitanici i metode: $\cup$ retrospektivnoj studiji analiziran je 71 ispitanik operisan na Klinici za neurohirurgiju u Banjoj Luci, u periodu od 2009. do 2016. godine. Kod 41 ispitanika urađena je ekstirpacija diska, dok je kod 30 ispitanika uz ekstripaciju diska dodatno oslobođen i korijen nerva. Svi pacijenti su operisani pod istim uslovima.

Rezultati: Ne postoji statistički značajna razlika u životnoj dobi žena i muškaraca liječenih klasičnom discektomijom i foraminotomijom. Postoji statistički značajna razlika u protruziji i ekstruziji diskusa kod pacijenata kod kojih je rađena klasična discektomija i pacijenata kod kojih je, uz klasičnu discektomiju, rađena i foraminotomija. Ne postoji statistički značajna razlika u dijagnostici kod ispitanika kod kojih je urađena klasična discektomija i onih kod kojih je, uz klasičnu disektomiju, rađena i foraminotomija. Postoji statistički značajna razlika u jačini bola kod pacijenata kod kojih je urađena klasična discektomija i pacijenata kod kojih je, uz klasičnu discektomiju, rađena i foraminotomija. Značajna je statistička razlika u kliničkom oporavku - nalaz u korist ispitanika kod kojih je rađena foraminotomija u odnosu na ispitanike kod kojih je urađena klasična discektomija.

Diskusija: Liječenje ovog sindroma je kompleksno i multidisciplinirano sa problematičnim uspjehom, a ukoliko se radi operacija, rezultati nisu tako dobri kao kod primarne operacije.

Zaključak: Rezultati ove studije pokazuju da pacijenti kojima je u sklopu operacije prolapsa lumbalnog diska urađena i foraminotomija imaju klinički bolji rezultat.

Ključne riječi: Foraminotomija, discektomija, protruzija, ekstruzija 